\title{
楖子油及びバタ一が胃内容排出に 及ぼす影響に就いて
}

厚生省研究所或皆策登部

福 井忠孝鈴 木 哲 郎

I. 緒論

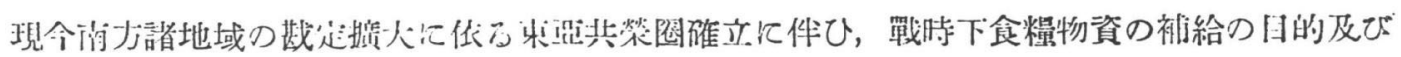

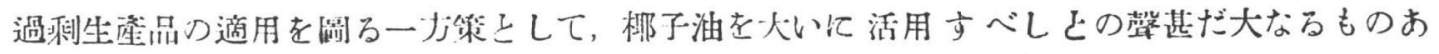

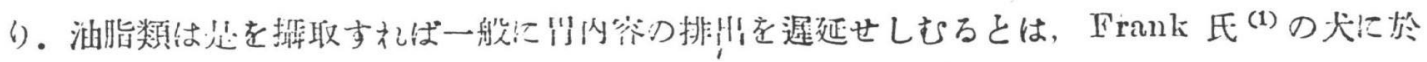

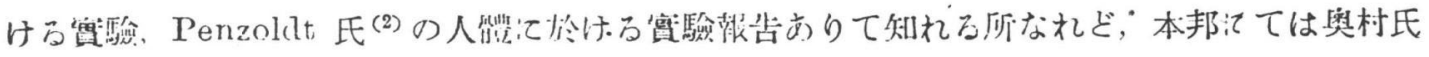

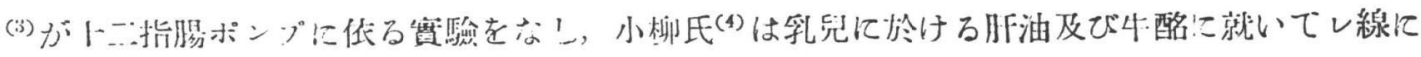

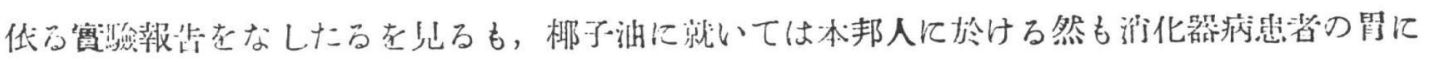

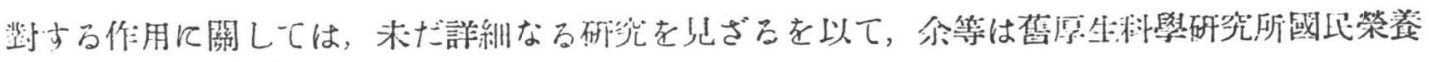

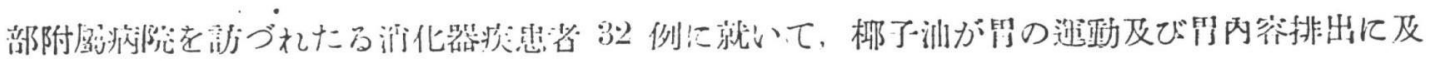

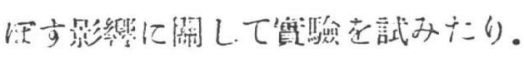

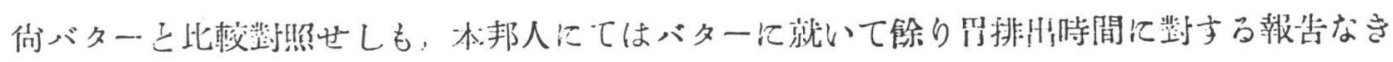

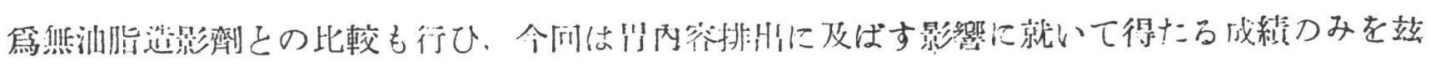
に教奨せんと文。

\section{II. 實驗}

\section{(1) ز ز 江}

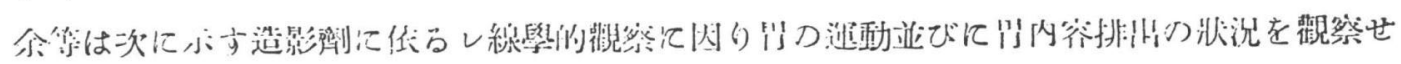

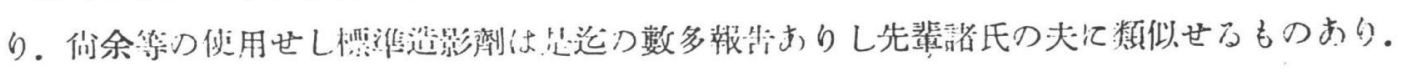

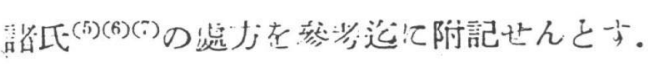

（1）造影彻远才j

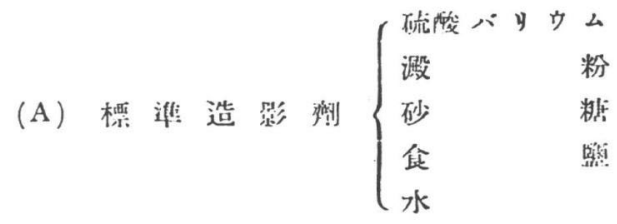
$70 \mathrm{~g}$
$7 "$
$10 "$
$0.5 "$

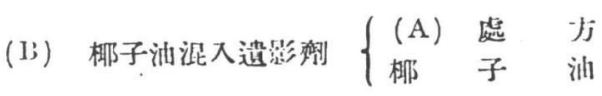
[ii] $10 \stackrel{\text { 上 }}{\mathrm{g}}$
(C) バター混入造影制 $\left\{\begin{array}{lll}(\mathrm{A}) & \text { 處 } & -J j \\ \text { ハ } & \text { 夕 } & -\end{array}\right.$
[i] $10 \mathrm{~g}$ 
登考附訅：

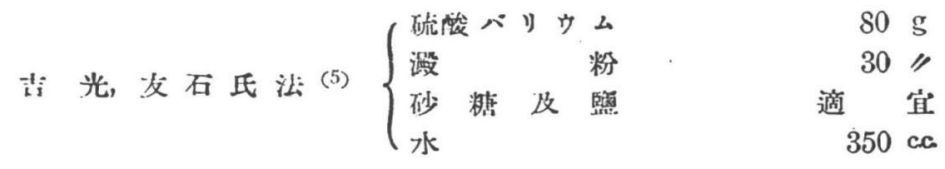

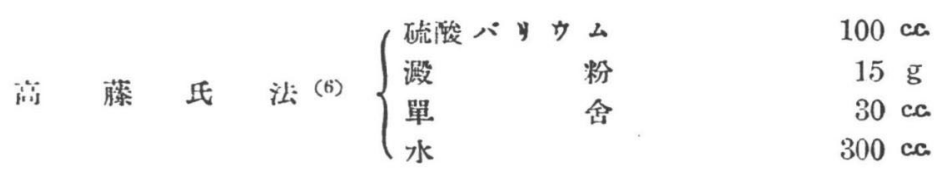

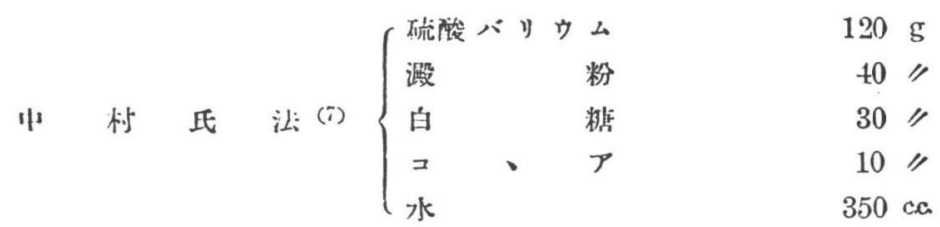

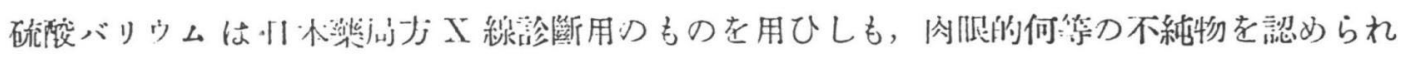

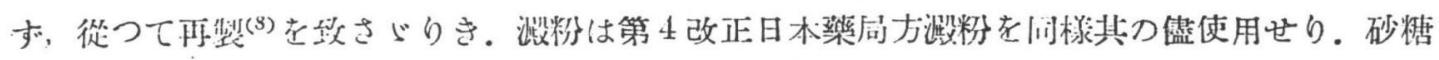

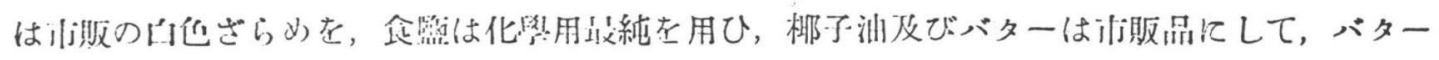
は雪印を用ひたり。

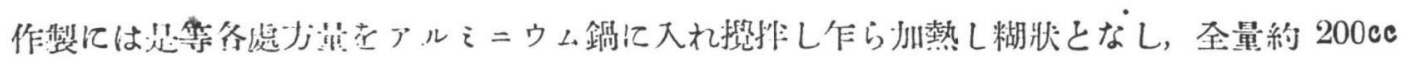

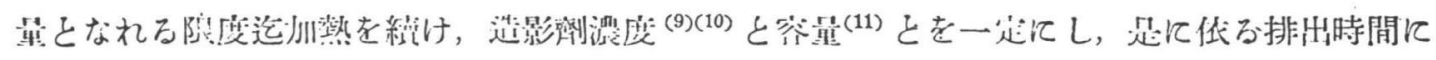

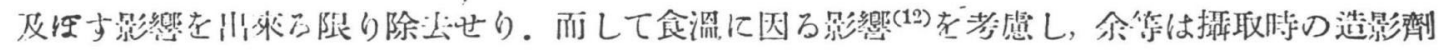

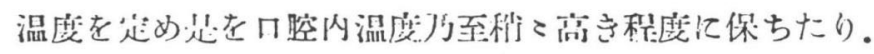

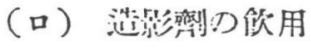

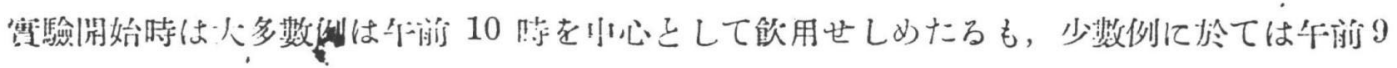

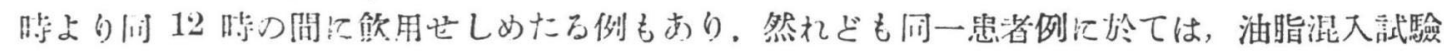

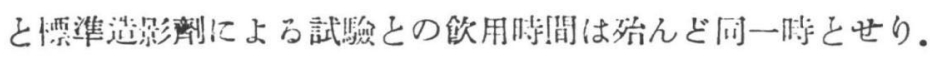

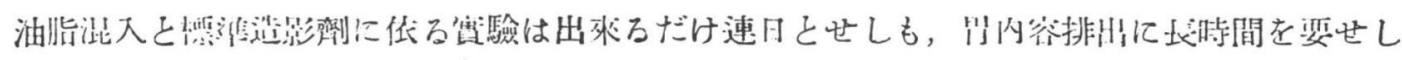

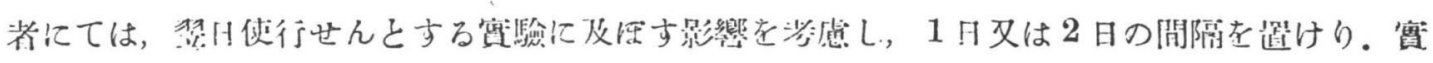

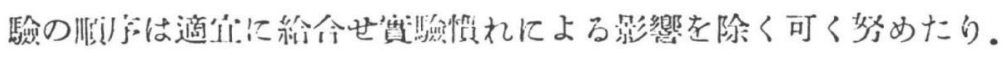

(2) 被倵䲆留者 (32 例)

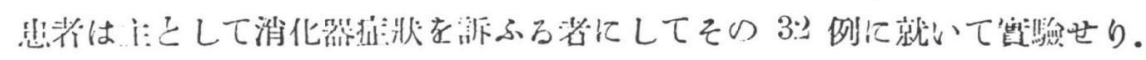

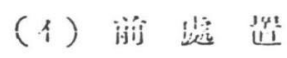

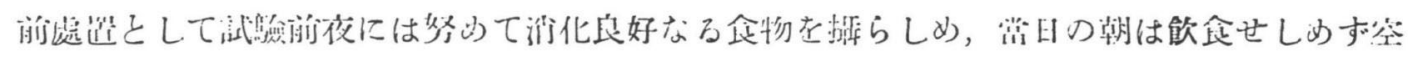

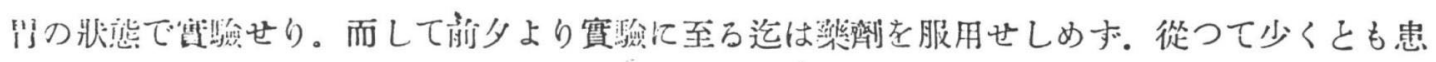

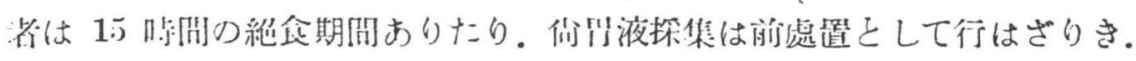

(口) 然 施

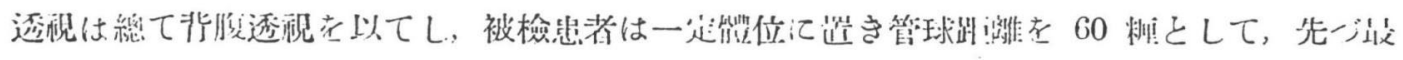




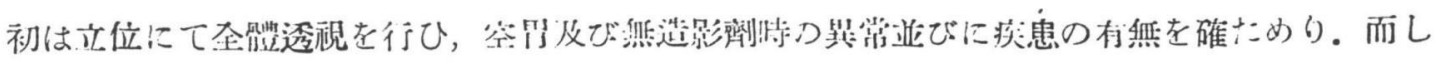

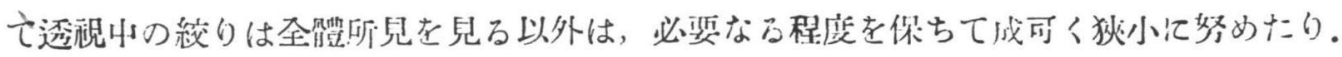

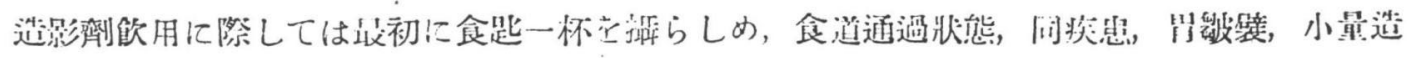

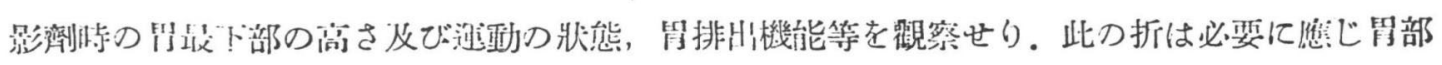

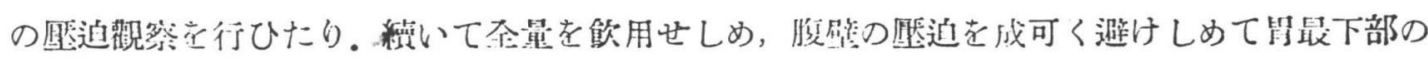

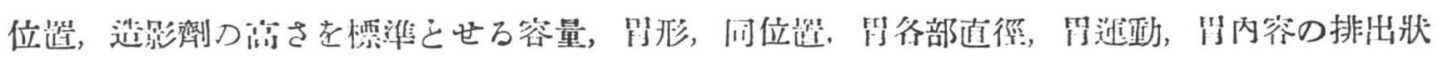
华, 罗液分必望，十二指晹球部の狀態江注甞在讲へ门。

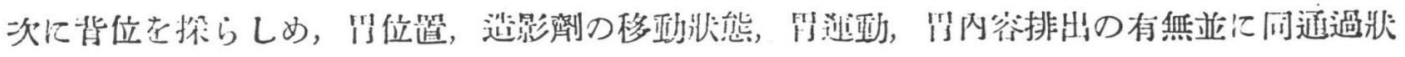

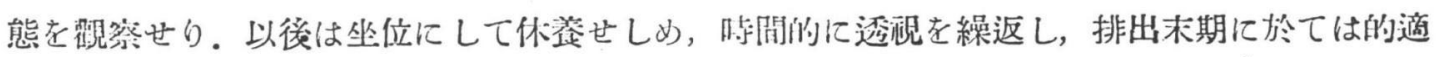

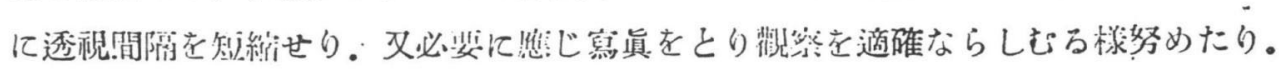

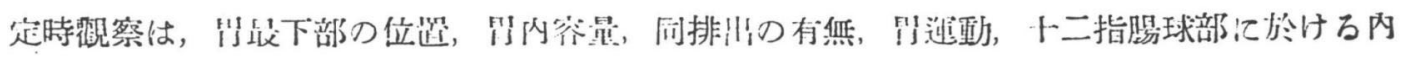
享つ有無等に就いてのみ微察せり。

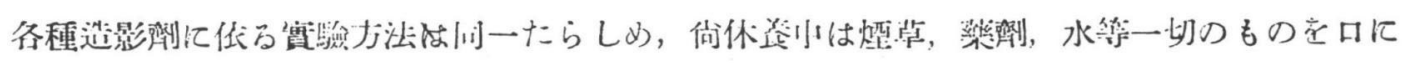
することを森じたり。

\section{III. 實 驗 成 績}

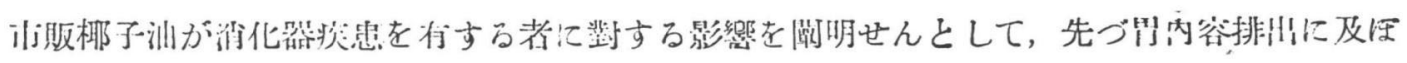

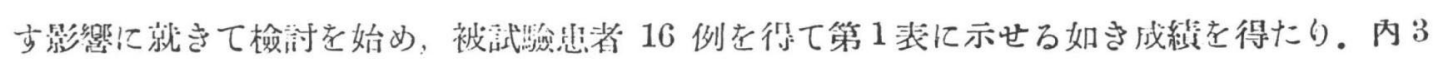

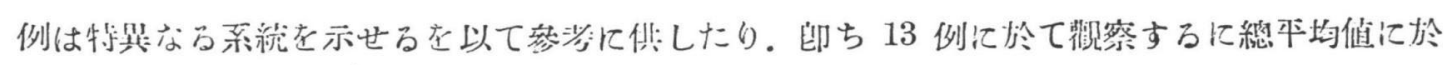

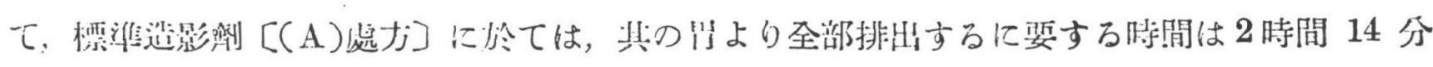

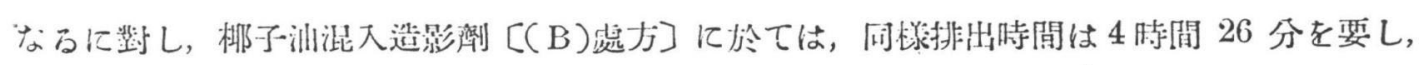

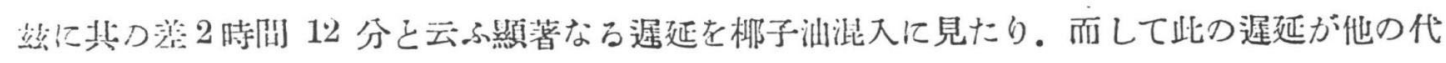

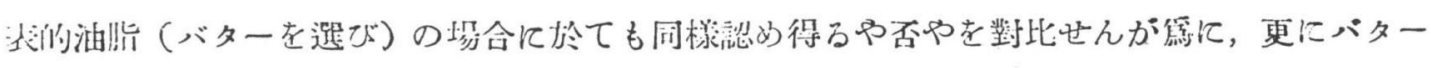

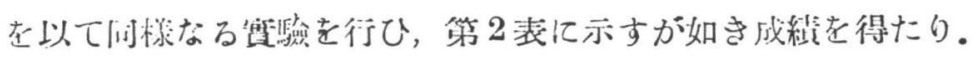

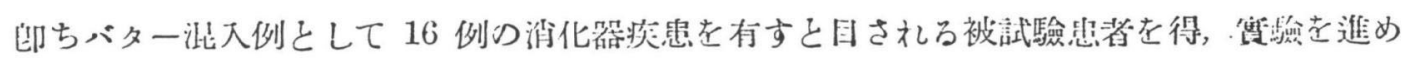

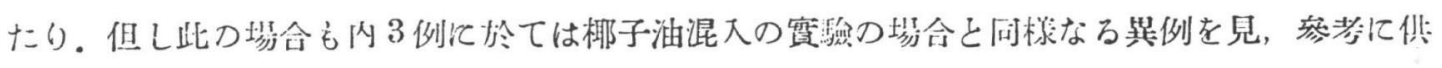
するるに止めたり。

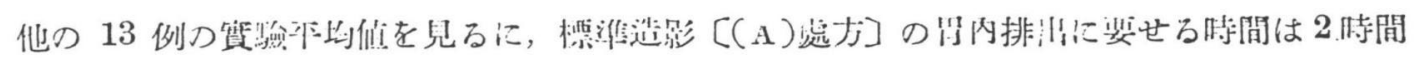

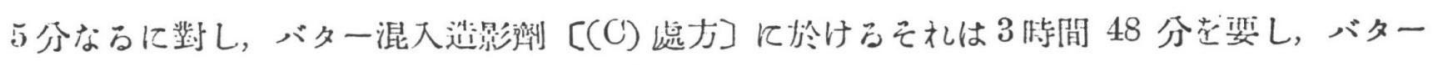

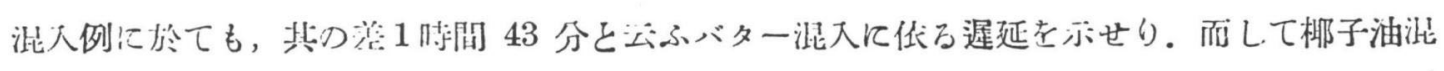

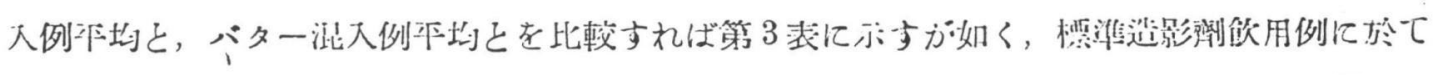

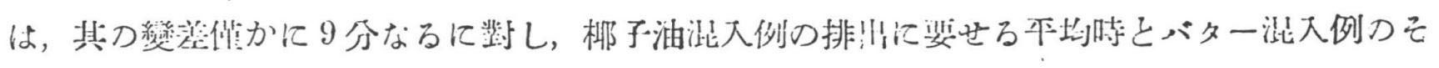

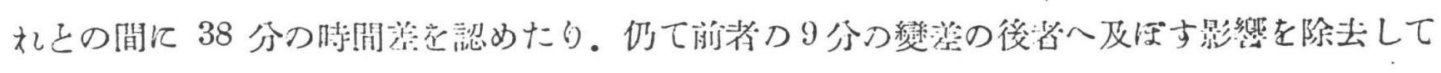

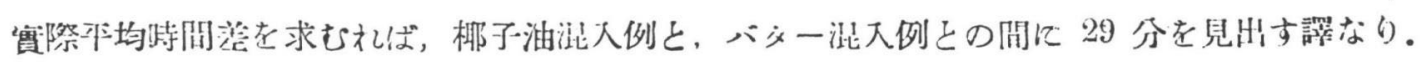




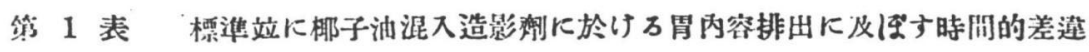

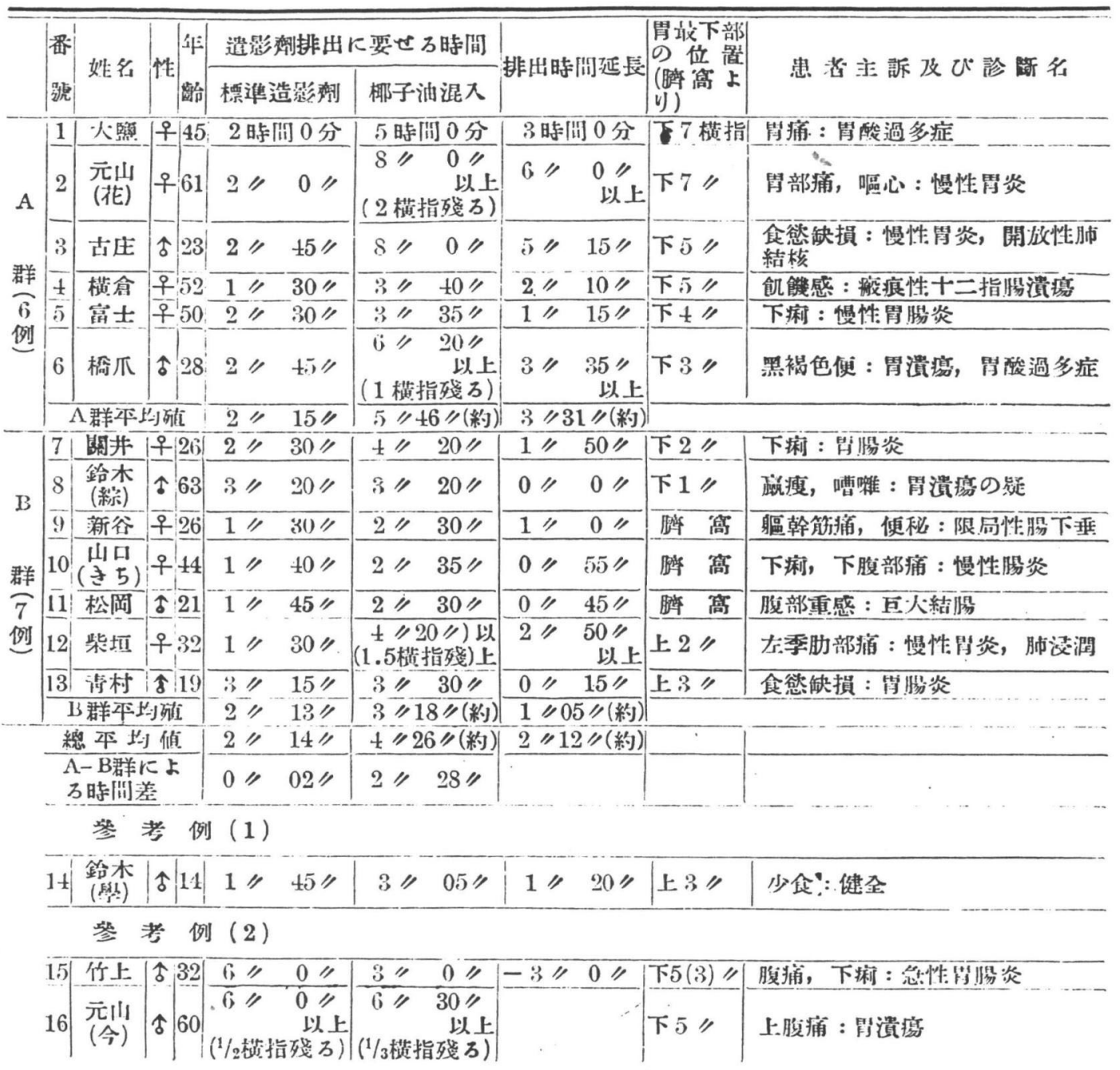

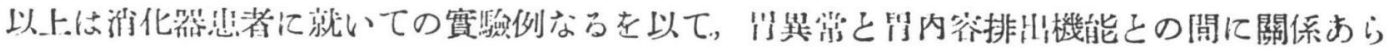

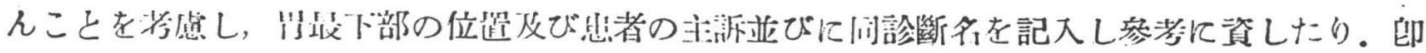

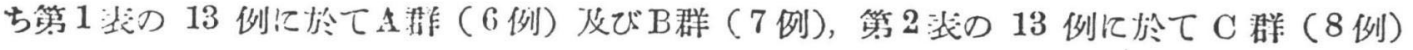

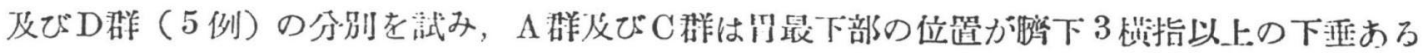

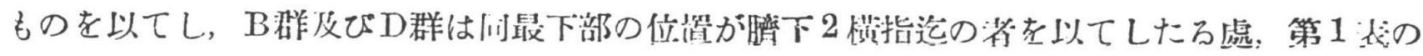

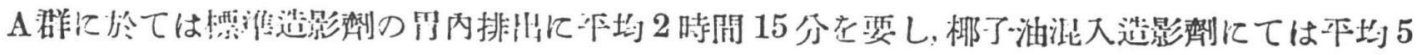

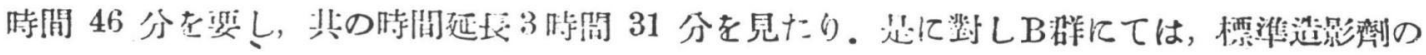

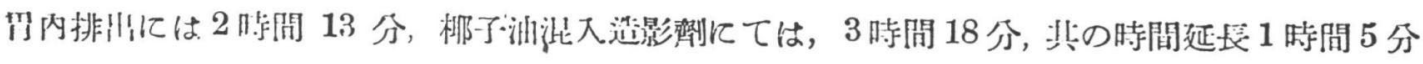

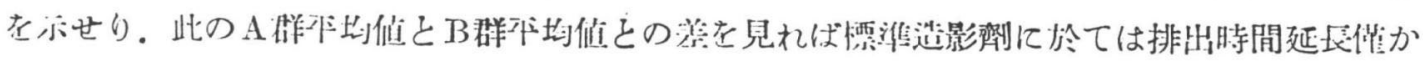

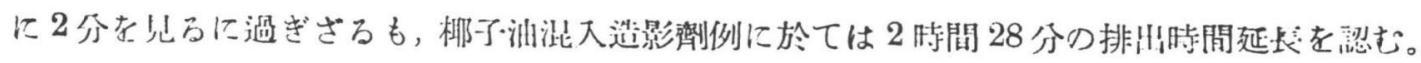




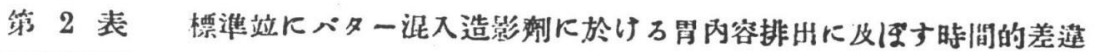

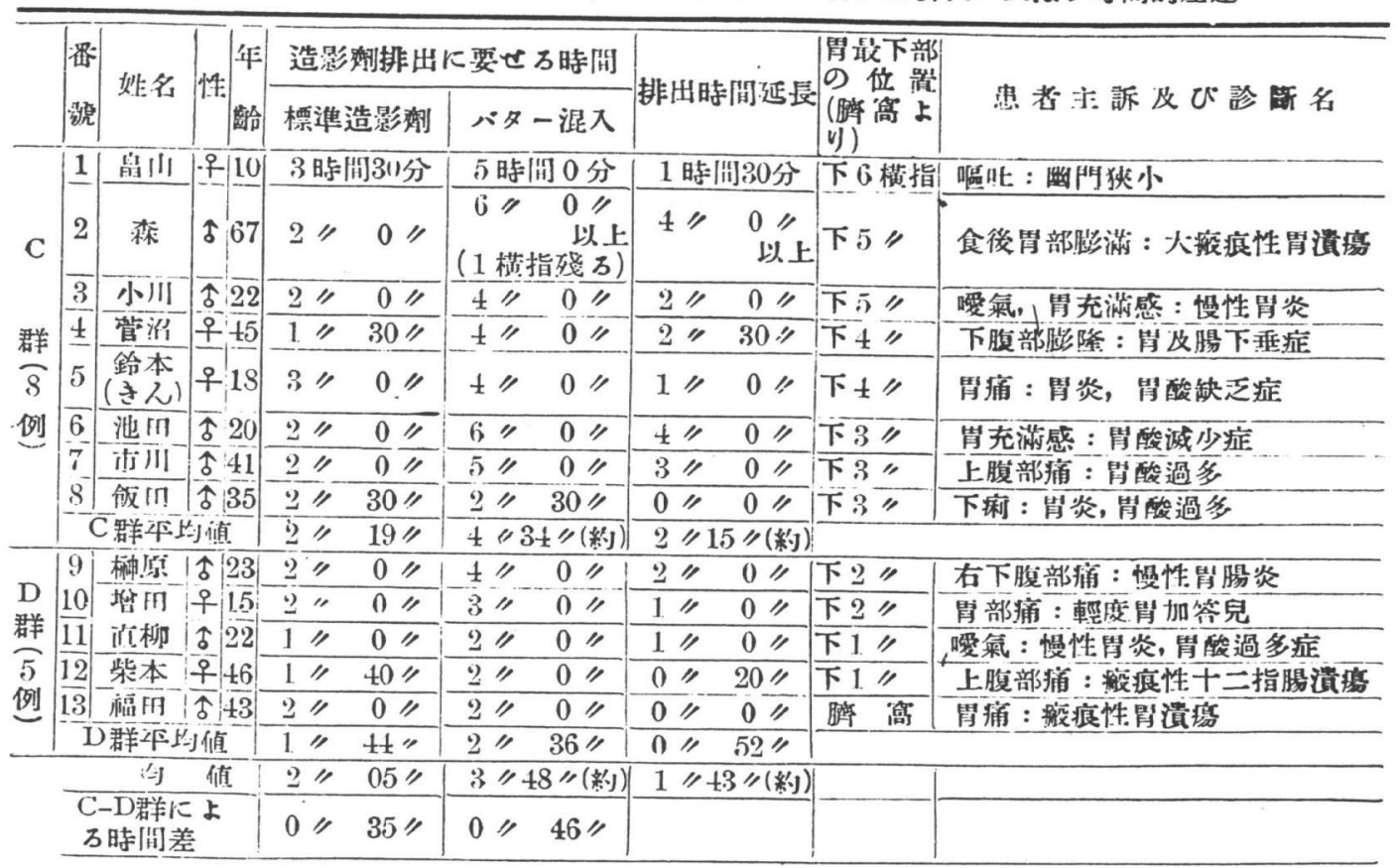

曑考例 (1)'

$14 \mid$ 松田 $|\hat{\delta}| 15 \mid$ 2" 0 " 3 " 0 " 1 " 0 " 0 " 1 " 1 " 少食: 健全

答惹例 $(2)^{\prime}$

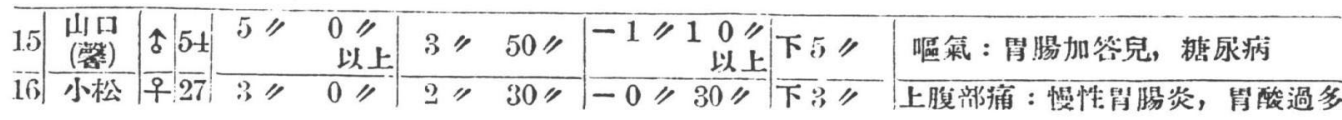

第。 3 表

\begin{tabular}{|c|c|c|c|c|}
\hline \multirow[b]{2}{*}{ (1) } & \multicolumn{2}{|c|}{ 造影䍃排出に要さ万時䦌 } & \multirow{2}{*}{\multicolumn{2}{|c|}{ 排出時閌延辰 }} \\
\hline & 標售造影劑 (A) & (B) xは (C)造影确 & & \\
\hline 第 1 表群 13 例平域裇 & 2 時成 14 分 & 4 時䦌 26 分 & 2 時润] & 12 分 \\
\hline 管 2 表群 13 例平均值 & 0511 & $31148 /$ & 111 & 4311 \\
\hline 问 上 差 & 09 II & $38 /$ & 011 & $29 / 1$ \\
\hline 金 例 评娼 & $09 "$ & $07 "$ & 111 & $58 / 1$ \\
\hline
\end{tabular}

然 洘

第 1 及第 2 表健全苗? 例平均仵

$1 \geqslant 53 "$

3 " 03 "

1 " 10 "

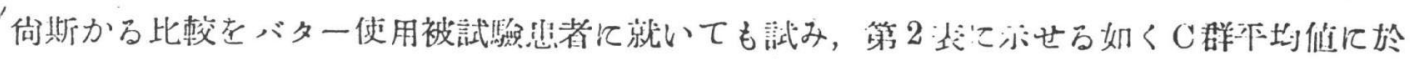

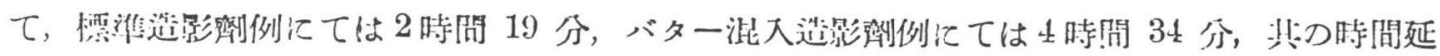

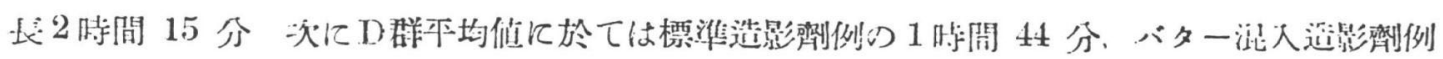
の2時閒36 分, 欺時間延龙 52 分を見たり。

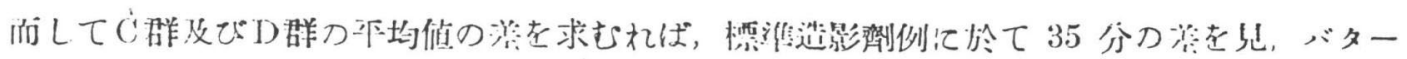


分; $\quad$ 袁

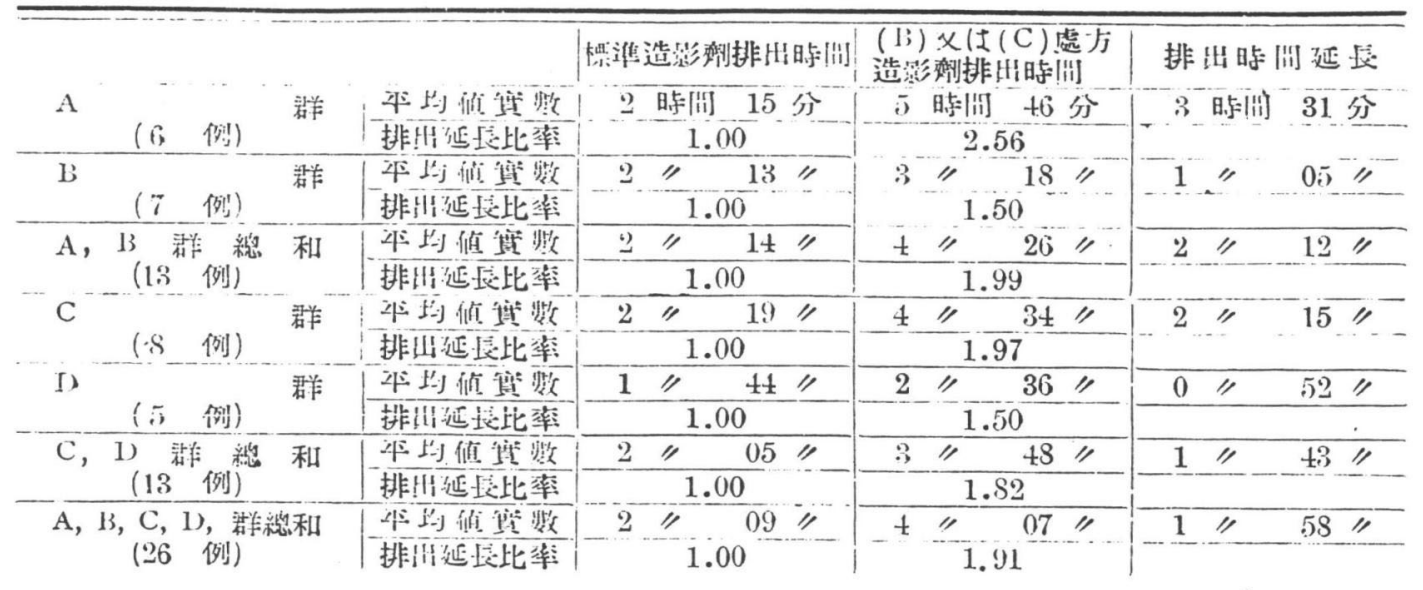

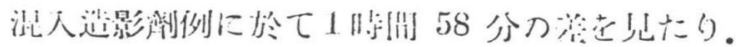

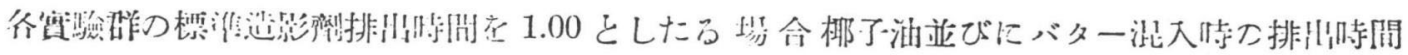

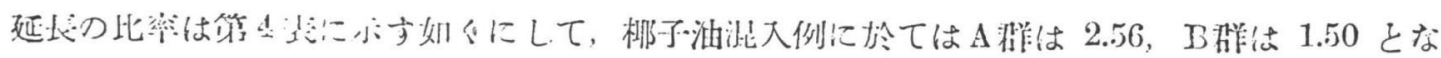

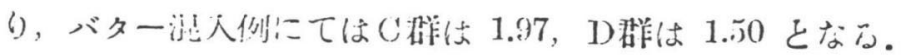

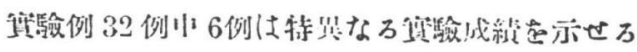

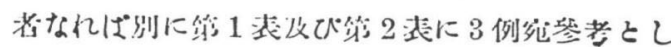

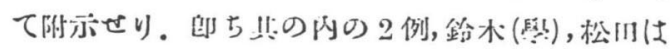

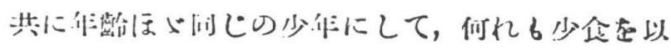

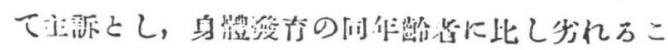

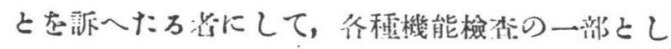

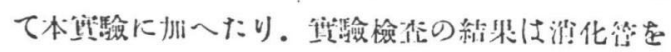

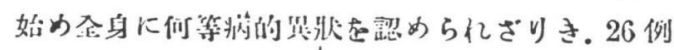

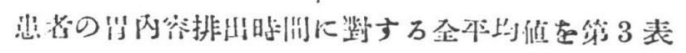

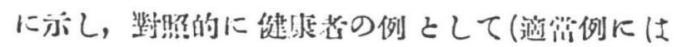

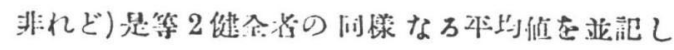
參考に資したり。

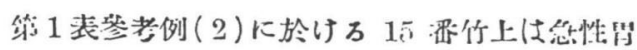

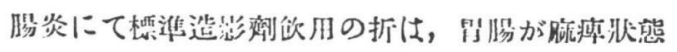

\section{IV. 總}

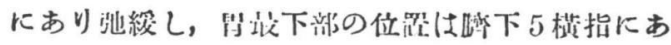

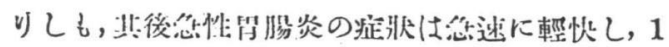

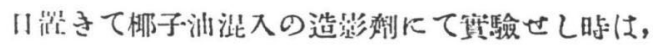

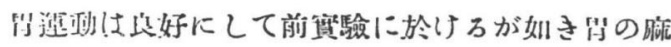

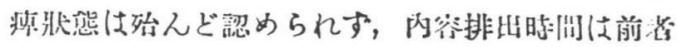
より 3 時润6短絃せり。

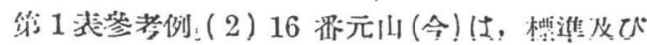

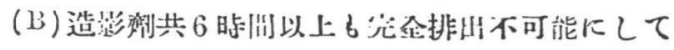
它全なっ㢳察を行ふ能はざりしものなり。

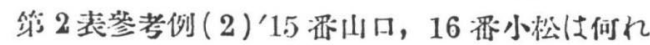

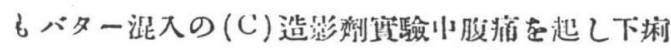

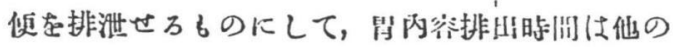

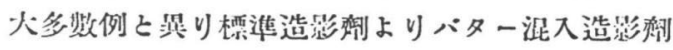

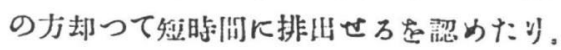

括

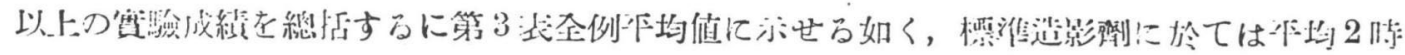

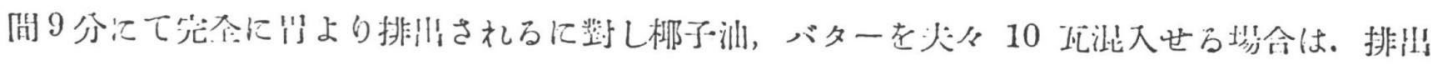

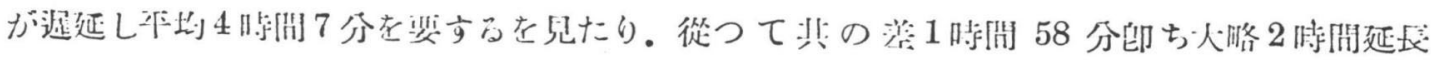

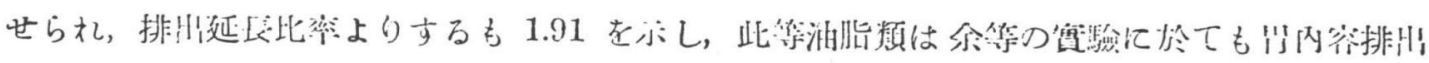
在掘延せしす怘作用する老泪めたり。

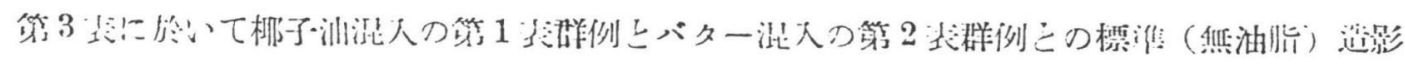




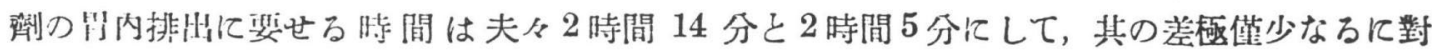
し，“柳子油混入時とバター混入较との比較にては夫々 4 時 26 閒分と 3 時問 48 分とにて，其

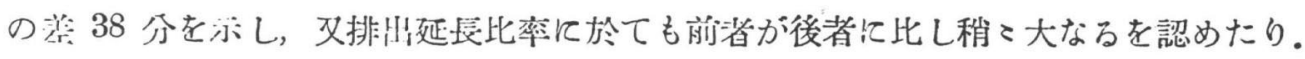

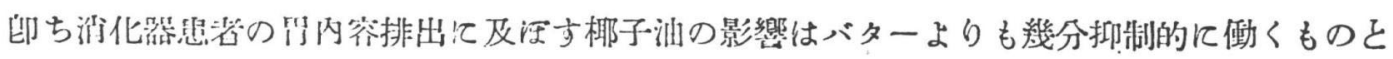

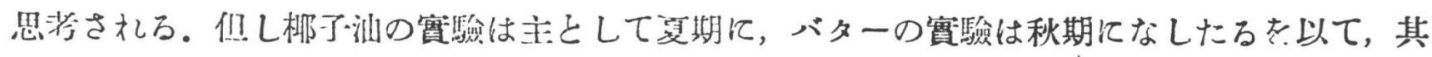
の季能的影㗊するわに就きては詳細なる實驗を更に行はんとす。

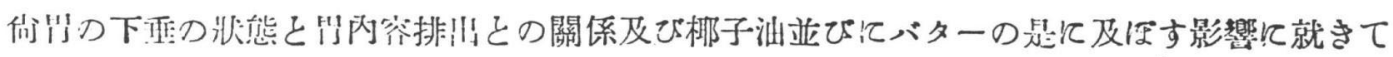

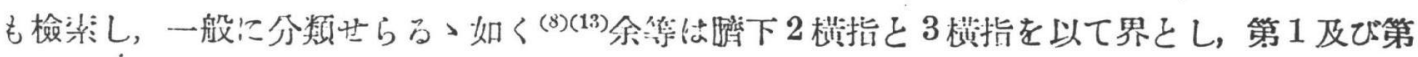

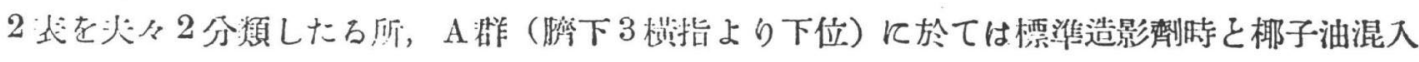

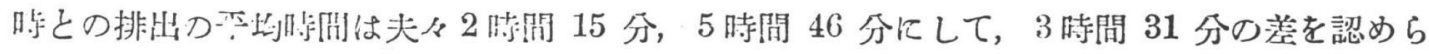

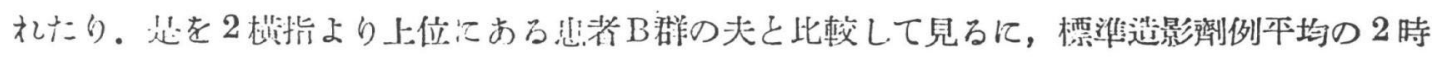

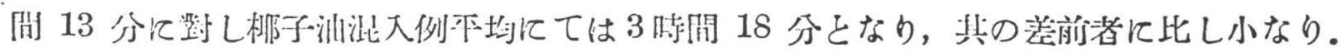

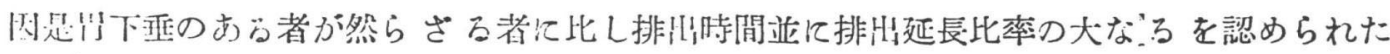

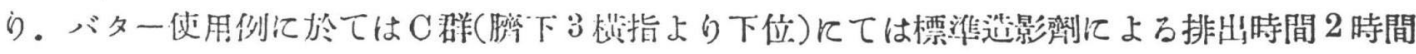

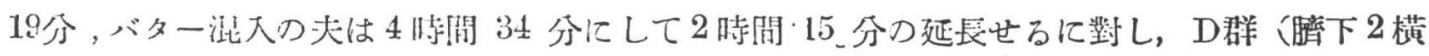
指より上倌）にては 1 㭙间 44 分と 2 时間 36 分にて 52 分す延長をし, 且つ其つ排出延長比

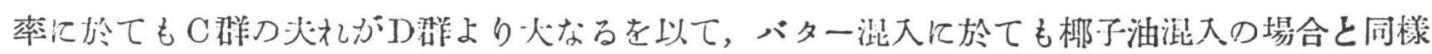

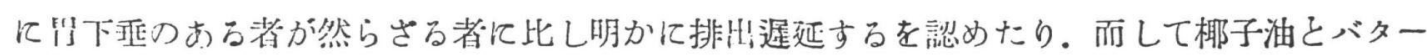

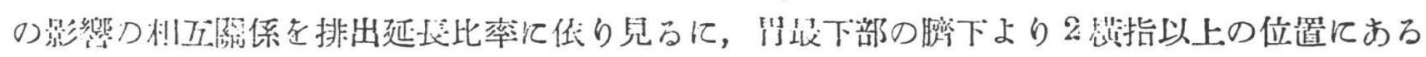

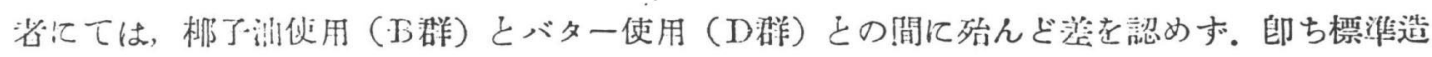

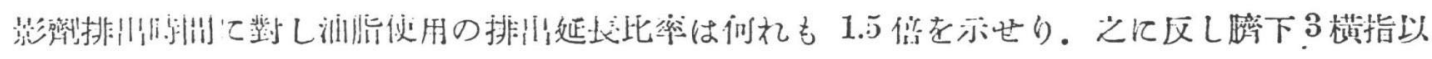

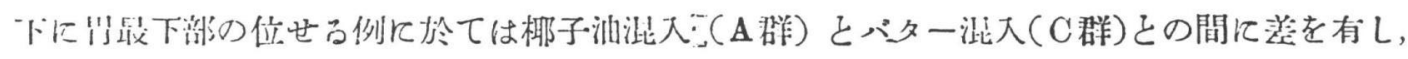

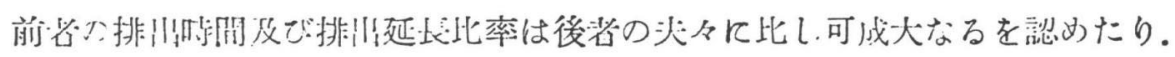

\section{$\nabla$. 結}

論

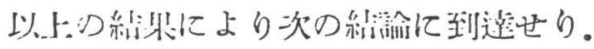

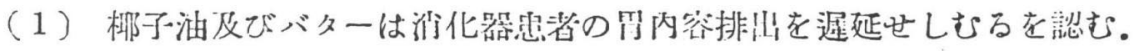

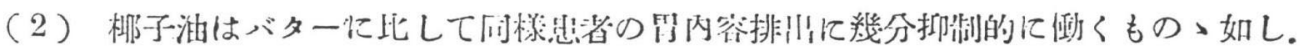

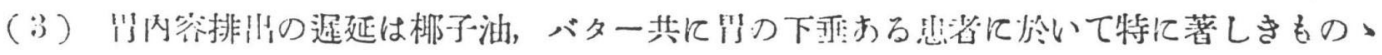
如くな゙け. 


\section{文䘞}

(1) Frank: Arch. f. Anat. u. Physiol. 3, 497, 1882. (2) Peuzoldt: Dtsch. Arch. f. Klin. Med. Bd. 51, S.535, 1893.

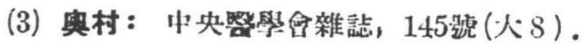

（4）小楖：辰懒㗨學

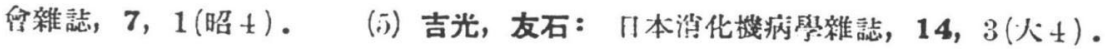

(6) 高藤: 㷊北

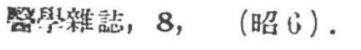

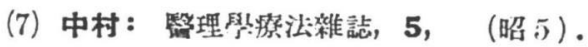

（8）加藤，中村：束京警

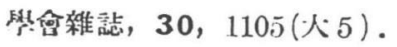

（9）久保：關西レントアンン協畣會誌，3(昭 3 )。

（10）國崎：日本 消化機病學誰誌，35，3(昭11).

（11）湯川：【!本消化機病學雜誌，5 (明39)。

(12) 山本: 實践 祭理祭，5年，6(昭10)。 (13) : 田宮：內科レントケ゚ン診到學，2(炤16).

(14) 留藤, 岩井: 日 本內科學会雜誌，11，762(人12)。

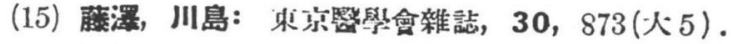

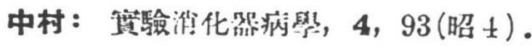

（17）小林：日本深化機病學雜詰，12，（大 2 ）。

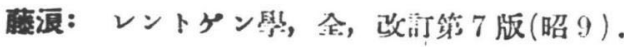

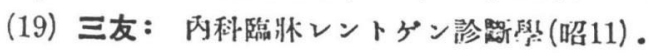

（20）鉿木：消化哭上線猃断學（昭15） 